\title{
Pengalaman Klinik Mahasiswa Fakultas Kedokteran Universitas Indonesia Tingkat $V$ di Departemen Ilmu Kesehatan Anak Rumah Sakit Dr. Cipto Mangunkusumo Jakarta
}

\author{
Irene, Soepardi Soedibyo, Hindra I. Satari \\ Departemen Ilmu Kesehatan Anak FKUI, RS Dr. Cipto Mangunkusumo, Jakarta
}

\begin{abstract}
Latar belakang. Evaluasi yang berkesinambungan mengenai komponen-komponen dalam proses pembelajaran di Fakultas Kedokteran Universitas Indonesia (FKUI) mutlak dibutuhkan, yang berguna untuk melakukan perbaikan dan pengembangan yang dianggap perlu.

Tujuan. Membahas tentang paparan mahasiswa FKUI klinik terhadap kasus dan prosedur inti bidang pediatri selama menjalani rotasi di Departemen Ilmu Kesehatan Anak (IKA), serta mengetahui persepsi mereka mengenai peran supervisor.

Metode. Penelitian merupakan survei, deskriptif, potong lintang pada mahasiswa FKUI tingkat $\mathrm{V}$ tahun ajaran 2007-2008, yang telah melalui rotasi kepaniteraan IKA.

Hasil. Lebih 50\% dari 160 mahasiswa pernah menghadapi 10 dari 55 kasus yang terdapat dalam daftar kasus inti secara mandiri dan atau bersama-sama setidaknya satu kali. Lebih dari $50 \%$ mahasiswa pernah melakukan 7 dari 17 prosedur inti secara mandiri dan atau asistensi setidaknya satu kali. Lebih dari 50\% mahasiswa setuju dengan cara mengajar supervisor, dan menilai bahwa hubungan supervisor dengan mahasiswa adalah baik.

Kesimpulan. Paparan mahasiswa terhadap kasus dan prosedur inti bidang pediatri masih rendah. Ratarata mahasiswa setuju dengan cara mengajar supervisor, dan menilai bahwa hubungan supervisor dengan mahasiswa adalah baik. (Sari Pediatri 2009;10(5):285-91).
\end{abstract}

Kata kunci: Mahasiswa kedokteran, keterampilan klinik, kompetensi klinik

\footnotetext{
Alamat Korespondensi:

Prof. Dr. Soepardi Soedibyo, SpA(K). Pediatri Rawat Jalan Dep. Ilmu Kesehatan Anak FKUI. Divisi Nutrisi dan metabolik. Departemen Ilmu Kesehatan Anak FKUI-RSCM. Jl. Salemba no.6, Jakarta 10430. Telepon: 021- 3915179. Fax: 021-390 7743.

Dr. Irene. Jl. Diponegoro No. 71, Jakarta 10430 (021) 7312138/ 081210412334 irene_rusli@yahoo.com
}

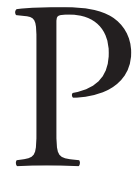
endidikan kedokteran saat ini mengalami perubahan pesat seiring kemajuan pada bidang medis, oleh karena itu keberadaan dokter yang kompeten makin dibutuhkan. Proses untuk menjadi seorang dokter yang kompeten tentunya dipengaruhi oleh banyak faktor penting, salah 
satunya adalah proses belajar dan mengajar dalam setiap jenjang pendidikan kedokteran. Institusi penyelenggara pendidikan kedokteran senantiasa mengacu pada tujuan pendidikan kedokteran secara umum, landasan hukum, dan kurikulum pendidikan.

Dalam pelaksanaannya, evaluasi terhadap suatu kurikulum harus dilakukan secara berkesinambungan agar kurikulum tersebut senantiasa relevan dan berkualitas sebagai acuan pendidikan. ${ }^{1-4}$ Pendidikan kedokteran di Indonesia saat ini berada dalam masa transisi, dengan rencana implementasi kurikulum yang baru, Standar Kompetensi Dokter menggantikan Kurikulum Inti Pendidikan Dokter Indonesia II (KIPDI II).

Proses pembelajaran merupakan suatu kegiatan belajar mengajar menyangkut kegiatan tenaga pendidik, kegiatan peserta didik, pola dan proses interaksi tenaga pendidik dan peserta didik serta sumber belajar, dalam suatu lingkungan belajar dalam kerangka program pendidikan. ${ }^{5}$ Paradigma pembelajaran dalam berbagai bidang pendidikan tinggi telah mengalami perubahan. Paradigma baru menempatkan mahasiswa sebagai personal yang lebih mengendalikan aktivitas belajar. Maka institusi penyelenggara pendidikan kedokteran pada masa sekarang dituntut untuk dapat menciptakan suasana kondusif dan memfasilitasi sarana yang mendukung suksesnya proses pembelajaran. ${ }^{6}$

Pendidikan profesi bagi seorang sarjana kedokteran bertujuan menyiapkan sarana untuk menerapkan keahlian dokter. ${ }^{7}$ Tujuan pendidikan kedokteran sangat didukung oleh penguasaan ilmu pengetahuan dasar dan pengalaman belajar dalam lingkup praktik klinik yang nyata, agar mahasiswa dapat terpapar dengan variasi kasus klinik. ${ }^{8,9}$ Pengalaman belajar mahasiswa tahap klinik tidak hanya berpusat di rumah sakit tingkat tersier, ${ }^{10,11}$ tetapi harus diperluas sampai instansi-instansi kesehatan tingkat yang lebih rendah. Instansi tersebut mencakup poliklinik rawat jalan, rumah sakit umum daerah, klinik dokter umum, dan sanatorium. Noble $\mathrm{dkk}^{12}$ mendapatkan bahwa praktik keterampilan klinik sejak dini memberikan dampak signifikan dalam meningkatkan perilaku profesional mahasiswa yang berorientasi pada pasien (patientcentred). Hal tersebut juga membangun kepercayaan diri mahasiswa untuk berkomunikasi dengan pasien.

Kegiatan pembelajaran tahap klinik tidak akan berlangsung dengan baik dan efektif tanpa seorang supervisor klinik. Supervisi klinik mempunyai dampak yang sangat positif karena akan mempengaruhi kepercayaan diri peserta didik, status moral, pengembangan pemahaman ilmu pengetahuan, dan kepuasan kerja. ${ }^{13}$ Chatenay dkk ${ }^{14}$ membuktikan bahwa paparan yang tinggi terhadap kasus gawat darurat, kritik, dan masukan dari supervisor merupakan faktor-faktor yang akan mempengaruhi hasil ujian.

\section{Metode}

Penelitian survei, deskriptif dengan desain potong lintang, dilakukan selama bulan Juni 2008, di Departemen Ilmu Kesehatan Anak FKUI, Rumah Sakit Cipto Mangunkusumo (RSCM) Jakarta. Data primer diperoleh dengan menggunakan kuesioner yang dibagikan kepada semua mahasiswa tingkat $\mathrm{V}$ FKUI tahun ajaran 2007-2008 yang telah melalui rotasi kepaniteraan di Departemen Ilmu Kesehatan Anak. Mahasiswa yang sedang melakukan rotasi luar atau berhalangan saat kuesioner dibagikan, tidak diikutsertakan dalam penelitian. Daftar kasus dan prosedur inti bidang pediatri merujuk pada Tujuan Instruksi Umum, Tujuan Perilaku Khusus Departemen IKA FKUI tahun 2000, dengan deskripsi tingkat kemampuan mahasiswa C3 P3, dengan atau tanpa A3. ${ }^{15}$ Kasus inti terdiri dari masalah kesulitan makan, obesitas, defisiensi vitamin dan mineral, diare dengan dan tanpa dehidrasi, perdarahan saluran cerna, hepatitis virus, kolestasis, perdarahan akibat hipertensi porta, kejang demam, status epileptikus, infeksi pada neonatus, anemia pada neonatus, neonatus dengan perdarahan, syok pada neonatus, asfiksia neonatorum, infeksi saluran napas atas, sinusitis, otitis media akut, epiglotitis akut, laringitis akut dan sindrom croup, emfisema, atelektasis, reaksi anafilaksis, urtikaria, anemia defisiensi Fe, thalassemia, anemia aplastik, purpura trombositopenia idiopatik, varisela, morbili, rubella, difteri, tetanus, demam berdarah dengue kandidiasis dan infeksi nosokomial. Prosedur-prosedur inti terdiri dari tindakan pemberian imunisasi, pungsi lumbal, perawatan segera pada neonatus, tindakan pungsi pleura, resusitasi kardiopulmoner pada bayi dan anak.

Paparan mahasiswa terhadap kasus dan prosedur inti bidang pediatri dibagi dalam beberapa derajat paparan yaitu 1) pernah menghadapi dan ikut menangani kasus inti (melakukan anamnesis, pemeriksaan fisis, penentuan diagnosis dan diagnosis banding, rencana tata laksana, edukasi/konseling, 
yang dilakukan secara mandiri dan / bersama-sama), setidaknya 1 kali; 2) pernah menghadapi kasus inti, hanya sekedar observasi, setidaknya 1 kali; 3) tidak pernah menghadapi kasus inti; 4) pernah melakukan prosedur klinik inti (melakukan secara mandiri dan / asistensi), setidaknya $1 \mathrm{kali}$; 5) hanya observasi/ melihat prosedur klinik inti yang sedang dilakukan, setidaknya 1 kali; tidak pernah melakukan/melihat prosedur klinik inti.

Untuk mengetahui persepsi mahasiswa mengenai supervisor digunakan alat evaluasi subjek yang dikembangkan oleh Griffith Institute for Higher Education, Universitas Griffith, Queensland. ${ }^{16}$ Alat evaluasi tersebut direkomendasikan oleh konsultan bidang pendidikan kedokteran dari Universitas Griffith, Queensland, dalam proyek Quality of Undergradute Education tahun 2000-2004 di FKUI, dan pernah diuji-cobakan di Departemen IKA pada tahun 2003. Setiap pertanyaan mengenai persepsi mahasiswa terhadap supervisor memiliki 6 skala penilaian menurut Likert, yaitu (1) sangat setuju, (2) setuju, (3) tidak yakin, (4) tidak setuju, (5) sangat tidak setuju, dan (6) tidak tahu. Persepsi mahasiswa mengenai cara mengajar dan hubungan antara supervisor dan mahasiswa dinilai berdasarkan nilai rerata dan standar deviasi. Rata-rata mahasiswa setuju dengan cara mengajar dan adanya hubungan yang baik antara supervisor dan mahasiswa, berdasarkan pernyataan yang terdapat pada kuesioner, bila mendapat nilai 2. Jumlah mahasiswa yang setuju dengan cara mengajar dan adanya hubungan yang baik antara supervisor dan mahasiswa, berdasarkan pernyataan yang terdapat pada kuesioner, sama dengan jumlah mahasiswa yang tidak setuju bila mendapat nilai 3. Rata-rata mahasiswa tidak setuju dengan cara mengajar dan tidak terdapatnya hubungan baik antara supervisor dan mahasiswa, berdasarkan pernyataan yang terdapat pada kuesioner, bila mendapat nilai 4 .

\section{Hasil}

Jumlah seluruh mahasiswa sebagai responden adalah 160 dari 220 mahasiswa tingkat $\mathrm{V}$ yang telah mengikuti rotasi kepaniteraan di Departemen IKA $(72,7 \%)$. Tabel 1 menunjukkan separuh responden (51\%) berada pada kelompok usia 20-22 tahun, diikuti oleh $43 \%$ responden dengan kelompok usia 23-25 tahun. Sekitar 49\% responden adalah mahasiswa perempuan. Berdasarkan jumlah mahasiswa dalam grup rotasi, hanya grup $\mathrm{V}$ saja yang seluruh mahasiswanya menjadi responden dalam penelitian ini, mewakili $\pm 30 \%$ populasi responden.

Tabel 1. Karakteristik subjek penelitian

\begin{tabular}{lcc}
\hline Karakteristik & $\mathrm{n}(160)$ & $\%$ \\
\hline Usia (tahun) & & \\
$20-22$ & 82 & 51,3 \\
$23-25$ & 69 & 43,1 \\
$26-28$ & 2 & 1,3 \\
$29-31$ & 1 & 0,6 \\
Tidak ada data & 6 & 3,8 \\
Jenis kelamin & & \\
Laki-laki & 66 & 41,2 \\
Perempuan & 78 & 48,8 \\
Tidak ada data & 16 & 10 \\
Kelompok & & \\
I & 29 & 18,1 \\
II & 30 & 18,8 \\
III & 19 & 11,9 \\
IV & 36 & 22,5 \\
V & 46 & 28,8 \\
\hline
\end{tabular}

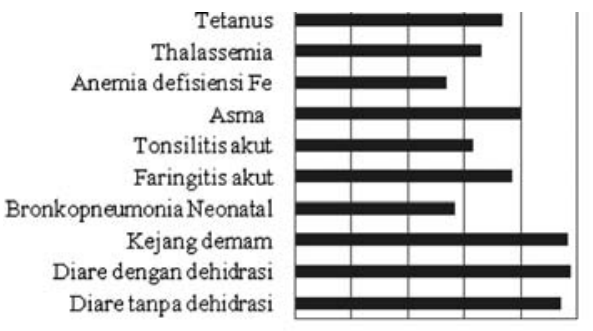

$0,0 \quad 20,0 \quad 40,0 \quad 60,0 \quad 80,0 \quad 100,0$

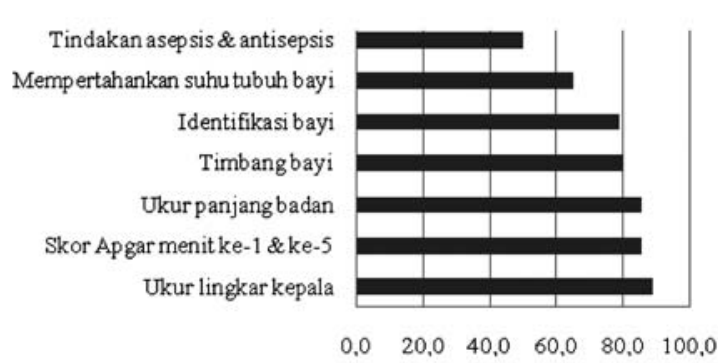

$\begin{array}{llllll}0,0 & 20,0 & 40,0 & 60,0 & 80,0 & 100,0\end{array}$

Grafik 1. Distribusi kasus dan prosedur inti yang terpapar pada lebih dari $50 \%$ mahasiswa 


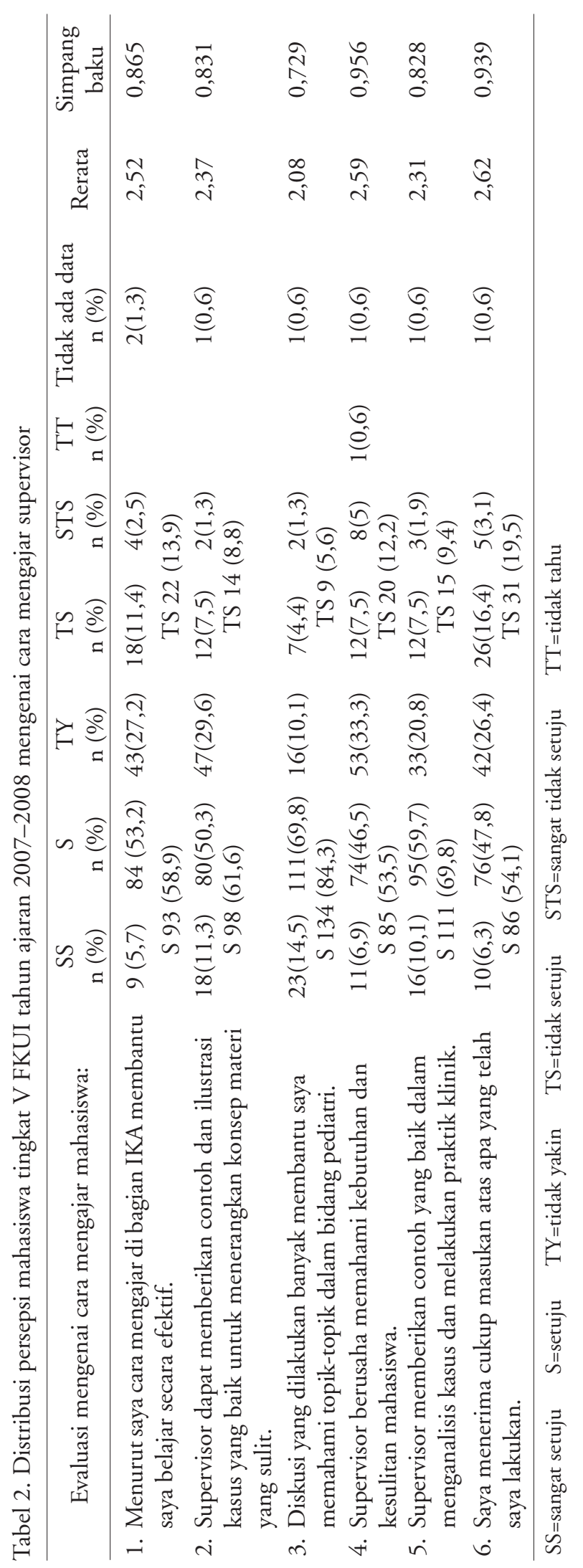


Grafik 1 menunjukkan bahwa lebih dari 50\% mahasiswa terpapar dengan 10 dari 55 kasus yang terdapat dalam daftar kasus inti pediatri, diwakili oleh 2 kasus gastroenterologi, satu kasus neurologi, 1 kasus perinatologi, 3 kasus respirologi, 2 kasus hematologi dan satu kasus infeksi. Kasus-kasus ini dihadapi oleh mahasiswa secara mandiri dan atau bersamasama setidaknya 1 kali. Lebih dari 50\% mahasiswa melakukan 7 dari 17 prosedur yang terdapat dalam daftar prosedur inti bidang pediatri secara mandiri dan atau asistensi setidaknya 1 kali. Ketujuh prosedur tersebut merupakan tindakan perawatan segera pada neonatus.

Semua mahasiswa yang memilih sangat setuju dan setuju terhadap pernyataan-pernyataan yang menilai cara mengajar serta hubungan antara supervisor dan mahasiswa, dalam analisis kedua persepsi tersebut digabung sebagai mahasiswa yang setuju terhadap pernyataan-pernyataan tersebut. Sebaliknya, semua mahasiswa yang tidak setuju dan sangat tidak setuju, dalam analisis kedua persepsi tersebut digabung sebagai mahasiswa yang tidak setuju terhadap pernyataanpernyataan tersebut. Tabel 2 menunjukkan lebih dari 50\% mahasiswa setuju dengan cara mengajar supervisor di Departemen IKA FKUI - RSCM. Rerata pada setiap komponen cara mengajar supervisor terdistribusi pada nilai 2, bermakna bahwa rata-rata mahasiswa setuju dengan setiap pernyataan pada komponen cara mengajar supervisor.

Tabel 3 menunjukkan bahwa lebih dari 50\% mahasiswa menilai adanya hubungan yang baik antara supervisor dan mahasiswa. Rerata pada setiap komponen hubungan antara supervisor dan mahasiswa terdistribusi pada nilai 2, bermakna bahwa rata-rata mahasiswa setuju dengan setiap pernyataan pada komponen hubungan antara supervisor dan mahasiswa.

Pendapat terbanyak dari mahasiswa mengenai kurangnya paparan mereka adalah karena jumlah serta variasi kasus dan tindakan yang kurang, diikuti oleh terbatasnya kesempatan mahasiswa untuk melakukan suatu tindakan yang biasanya langsung dilakukan oleh Peserta Pendidikan Dokter Spesialis (PPDS), perawat, dan bidan. Pendapat lainnya yang cukup mewakili adalah mengenai kurangnya waktu rotasi yang berdampak pada waktu yang terbatas untuk terpapar dengan pasien di bangsal dan poliklinik. Tidak ikut serta mahasiswa dalam melakukan follow up pasien di bangsal yang dialami selama rotasi di RSCM juga merupakan alasan akan kurangnya variasi paparan terhadap kasus-kasus pediatri.

\section{Diskusi}

Kekhawatiran akan pengalaman profesi yang kurang mahasiswa kedokteran semakin dirasakan dewasa ini. Hal tersebut dialami secara nyata oleh mahasiswa kedokteran di Inggris. ${ }^{17}$ Laju responden di FKUI Departemen IKA sekitar 75\%, 30\% lebih tinggi dari laju responden dalam penelitian yang dilakukan oleh Cowan dkk tahun 1996 (dikutip dari Ahmed SF) ${ }^{11}$ mengenai paparan mahasiswa klinik dalam bidang pediatri. Peneliti menetapkan frekuensi dan sifat paparan mahasiswa pada setiap kasus dan prosedur inti untuk memungkinkan kejadian paparan. Hanya 10 dari 55 kasus pada daftar kasus inti pediatri yang pernah dihadapi dan ditangani secara mandiri dan atau bersama-sama oleh lebih dari 50\% mahasiswa, setidaknya satu kali paparan. Demikian pula hanya 7 dari 17 prosedur pada daftar prosedur inti yang dilakukan oleh lebih dari 50\% mahasiswa secara mandiri dan atau asistensi, setidaknya satu kali, yang seluruhnya merupakan tindakan perawatan segera neonatus. Sasaran belajar direncanakan dan dibuat oleh institusi pendidikan kedokteran untuk menjamin agar mahasiswa dapat menguasai ilmu pengetahuan dan keterampilan klinik inti sesuai lama pendidikan. ${ }^{18}$ Berbagai opini dan kendalapun dihadapi dalam menentukan keterampilan klinis mana yang dianggap inti dalam bidang pediatri dikutip dari Ahmed SF. ${ }^{11}$ Pedoman TIU TPK Departemen IKA FKUI tahun 2000 yang digunakan oleh peneliti sebagai panduan, agaknya terdiri dari kasus-kasus yang cenderung spesialistik sesuai divisi-divisi yang terdapat dalam Departemen IKA FKUI. Data survei kesehatan rumah tangga ${ }^{19}$ mengenai jenis morbiditas yang dapat mempengaruhi angka kematian anak di bawah usia 5 tahun ${ }^{20}$ mungkin dapat dijadikan sebagai panduan dalam menentukan kasus pediatri yang dianggap inti. Rotasi mahasiswa di berbagai instansi yang memberikan pelayanan primer pada pasien pediatri akan meningkatkan kesempatan mahasiswa untuk terpapar pada variasi kasus dan tindakan. ${ }^{10-11}$ Mahasiswa FKUI selama rotasi kepaniteraan di Departemen IKA tersebar di tiga rumah sakit, yaitu di dua rumah sakit umum (RSU) dan di RSCM sebagai rumah sakit tingkat tersier. Mahasiswa hanya berotasi di bangsal 
rawat inap pediatri di kedua RSU, sedangkan di RSCM mahasiswa berotasi di IGD, poliklinik rawat jalan dan bangsal rawat inap. Keadaan ini dapat mempengaruhi rendahnya variasi kasus yang dihadapi dan tindakan yang dapat dilakukan oleh mahasiswa. rumah sakit Dr. Cipto Mangunkusumo sebagai rumah sakit rujukan mempunyai sebaran kasus pediatri dengan tingkat komplikasi yang lebih sulit, biasanya di luar area ilmu pengetahuan dan kompetensi mahasiswa klinik.

Seorang pembimbing atau supervisor adalah figur yang sangat esensial dalam dunia pendidikan dokter. Banyak fungsi dan tanggung jawab yang dipegang oleh seorang supervisor dalam pendidikan kedokteran. Rotasi kepaniteraan akan efektif bila supervisi klinik berkualitas. Peran seorang supervisor klinik menjadi jauh lebih penting saat jumlah dan variasi kasus yang dihadapi oleh mahasiswa sedikit. ${ }^{21}$ Sedikitnya jumlah dan variasi kasus yang dihadapi oleh mahasiswa selama rotasi kepaniteraan tampak pada survei yang kami lakukan. Persepsi mahasiswa cukup baik mengenai cara mengajar supervisor serta kualitas hubungan antara supervisor dan mahasiswa. Namun, kecenderungan yang cukup tinggi (20\%-30\%) akan ketidakyakinan mahasiswa mengenai cara mengajar supervisor dan kualitas hubungan antara supervisor dan mahasiswa, perlu ditelaah lebih lanjut.

Peserta program dokter spesialis adalah komponen dalam suatu institusi pendidikan dokter yang dapat berperan sebagai guru dan contoh bagi mahasiswa kedokteran. Mereka mendalami ilmu pengetahuan dan lebih mengembangkan keterampilan klinik yang dimiliki dengan cara membimbing mahasiswa. ${ }^{22}$ Peneliti tidak mengikutsertakan PPDS sebagai komponen dalam penelitian, karena belum ada batasan yang jelas mengenai peran dan tanggung jawab PPDS IKA FKUI dalam membimbing mahasiswa klinik. Menurut pendapat mahasiswa, PPDS mempunyai peran dalam meningkatkan kesempatan mereka untuk terpapar dengan variasi kasus dan tindakan.

Keterbatasan penelitian adalah pada distribusi dan pengisian kuesioner yang tidak dilakukan pada tiap akhir rotasi kepaniteraan, kecuali pada grup V. Bias memori sangat mungkin terjadi dalam pengalaman kasus dan prosedur inti yang pernah dihadapi oleh mahasiswa, juga mempengaruhi persepsi mahasiswa dalam menilai cara mengajar supervisor serta kualitas hubungan antara supervisor dan mahasiswa. Kesulitan dalam memfasilitasi evaluasi subjek yang dilakukan oleh supervisor terhadap mahasiswa, mengumpulkan nilai akademik akhir rotasi kepaniteraan IKA dan nilai praktik klinik serta semua buku log mahasiswa, juga menjadi keterbatasan dalam penelitian, karena parameter-parameter tersebut dibutuhkan untuk melakukan analisis silang.

\section{Kesimpulan dan Saran}

Disimpulkan bahwa paparan mahasiswa terhadap kasus dan prosedur inti yang merujuk pada TIU-TPK Departemen IKA FKUI tahun 2000 terlalu rendah. Mahasiswa setuju dengan cara mengajar supervisor di Departemen IKA FKUI. Mahasiswa menganggap bahwa hubungan antara supervisor dengan mahasiswa cukup baik, namun tampak kecenderungan yang cukup tinggi akan ketidakyakinan mahasiswa mengenai cara mengajar supervisor dan kualitas hubungan antara supervisor dan mahasiswa

Sebagai saran perlu melakukan 1. Evaluasi sasaran belajar secara teratur dan berkesinambungan berdasarkan sebaran kasus pediatri terutama di tingkat pelayanan primer, dengan memperhitungkan kejadian wabah; 2. Mengadakan simulasi kasus dan prosedur bidang pediatri yang dianggap merupakan area kompetensi; 3. Memperluas ruang lingkup rotasi mahasiswa dengan mitra; 4. Membina kerja sama dengan rumah sakit umum lain yang berpotensi sebagai rumah sakit mitra membuat batasan yang tegas mengenai sumber daya manusia (SDM), peran, fungsi dan tanggung jawabnya dalam memberikan bimbingan kepada mahasiswa klinik; 5. Membentuk suatu tim untuk melakukan monitor dan evaluasi secara berkala terhadap fungsi dan tanggung jawab SDM dalam memberikan bimbingan kepada mahasiswa klinik; 6. Mulai melakukan survei mengenai kuantitas dan kualitas bimbingan yang diterima oleh mahasiswa, terutama di rumah sakit mitra; 7. Mengadakan pertemuan dan diskusi secara berkala antar supervisor, PPDS dan staf lembaga institusi mengenai teknik serta area ilmu dan keterampilan klinik praktis untuk membimbing mahasiswa; 8. Melakukan penelitian serupa dengan menambahkan parameter penilaian yang lebih spesifik.

\section{Daftar Pustaka}

1. Peyton L, Peyton R. Curriculum and course development. 
Dalam: Peyton JWR, penyunting. Teaching \& learning in medical practice. Hertz: Manticore Europe Ltd; 1998. h. 91-105.

2. Birden H, Page S. Twenty-first century medical education: health professional education \& curriculum innovation and implementation in Australian universities. Diunduh dari: http://www.encyclopedia.com. Diakses tanggal 8 April 2008.

3. American Student Association. Principles regarding medical education-curriculum design and content. Diunduh dari: http://www.amsa.org/about/ppp/meded.cfm. Diakses tanggal 8 April 2008.

4. Kurikulum Inti Pendidikan Dokter di Indonesia (KIPDI) II. Direktorat Jenderal Pendidikan Tinggi Departemen Pendidikan dan Kebudayaan. RI, 1993.

5. Teknis pendidikan. Badan Pengembangan \& Pemberdayaan SDM Kesehatan. Diunduh dari: http://www. bppsdmk.depkes.go.id/ Diakses tanggal 8 April 2008.

6. Soedibyo S. Setitik air di tengah padang pasir pendidikan. Jakarta: Balai Penerbit FKUI; 2008. h. 16-64.

7. Pendidikan profesi bidang kedokteran. Departemen Pendidikan Nasional Indonesia. Diunduh dari: http:// www.depdiknas.go.id/publikasi/Masadepan/II_XVIII_2001/ Diakses tanggal 19 Maret 2008.

8. Amaral E, Zeferino A, Nadruz W, Antonio MAG, Sarian L, Inhaia C. Successful accomplishment of educational goals with clinical experience at primary public care facilities. Med Teach 2007; 26:600-5.

9. Wimmers PF, Schmidt HG, Spinter TAW. Influence of clerkship experiences on clinical competence. Med Educ 2006; 40:450-8.

10. Amin Z, Eng KH. Basics in medical education. Singapore: Word Scientific, 2003. h. 13-265.

11. Ahmed SF, Hughes A. Clinical experience during the paediatric undergraduate Course. J R Soc Med 1999;92:293-8.
12. Noble LM, Kubacki A, Martin J, Lloyd M. The effect of professional skills on patient-centredness and confidence in communicating with patients. Med Educ 2007; 41:432-40.

13. Launer J. Supervision, mentoring and coaching: oneto-one learning encounters in medical education. Association for the Study of Medical Education, 2006

14. Chatenay M, Maguire T, Skakun E, Chang G, CookD, Warnock GL. Does the volume of clinical experiences affect performance of clinical clerks on surgery exit examinations? Am J Surg 1996; 172:336-72.

15. WHO. Educational handbook for health personnel. Edisi 6. World Health Organization, Genewa, 1998.

16. Griffith University. User's Guide to Subject Evaluation Software, Griffith Institute for Higher Education, Griffith University. 1995.

17. McManus IC, Richards P, Winder BC. Clinical experience of medical students. Lancet 1998; 351:802-3.

18. Darce J, Nicol M. The development of a clinical skills matrix to plan and monitor contemporary teaching of doctors and nurses. Med Teach 1996; 17:318-23.

19. Situasi kesehatan dan gizi dan issue kebijakan memasuki millennium ketiga. Diunduh dari: http://www.gizi.net/lain/ download/SKG-1.doc. Diakses tanggal 24 Juli 2008

20. Country health profile: Indonesia. World Health Organization. Diunduh dari: http://www.searo.who.int/ LinkFiles/Indonesia. Diakses tanggal 24 Juli 2008.

21. Dolman DHJM, Wolfhagen IHAP, Essed GGM, Scherbier AJJA, van der Vleuten CPM. The impacts of supervision, patient mix and number of students on the effectiveness of clinical rotations. Acad Med 2002;77:332-5.

22. Steward DE, Feltovich PJ. Why residents should teach: The parallel processes teaching and learning. Dalam: Edwards JC, Marier RL, penyunting. Clinical teaching for medical residents: Roles, techniques and programs. New York: Springer Publishing Co; 1988.h.3-14. 